\title{
POLITICAL PARTICIPATION OF WOMEN IN SELECTING LEGISLATIVE MEMBERS 2019-2024 PERIOD IN WEST SUMATERA PROVINCE
}

\author{
Hadi Prabowo ${ }^{1} \&$ Ismail $^{2}$ \\ ${ }^{1}$ Institut Pemerintahan Dalam Negeri (IPDN) \\ Email: hadi.prabowo@gmail.com \\ ${ }^{2}$ Institut Pemerintahan Dalam Negeri (IPDN) \\ Email: ismailnurdin@gmail.com
}

\begin{abstract}
The purpose of this study is to describe the factors causing the decline of women's involvement in the legislature in West Sumatra. The method used in this study is a qualitative method with descriptive type. The findings of this study indicate that the decline in representation of women in the West Sumatra DPRD from 7 people in the 2014-2019 period to 4 in the 2019-2024 period. This is due to (1) The perspective that considers the strong patriarchal paradigm in most Indonesian people, (2) Women have a multi-dual role to take care of domestic and public life, (3) People's mindset that tends to idolize brave men and bears to be elected, (4) Women do not choose women, meaning the low awareness of women to choose women legislative candidates, (5) Political organizations do not really have full commitment to empower women. Comprehensively, the role of women is very limited in policy making and decision making and leadership positions that are still held by men due to socio-cultural conditions which make it difficult for women to be fully involved in it.
\end{abstract}

Keywords: Participation, Women's Representation, Political Stage, Legislative.

\section{A. INTRODUCTION}

Indonesia was the first country in the Asia-Pacific region to form a special ministry to increase the role of women. Various women's activities that emerged since the New Order government both professional organizations and the work ties of her husband, PKK, Kowani, and others. This shows the increasing growth of women's political participation and has helped to carry out government programs. Various political positions have been achieved such as becoming ministers, parliamentarians, party heads, regents, sub-district heads, surahs, and others. But if seen from the number and influence in the formulation of national policy is very small. Women's participation in politics in the reform era is now experiencing an expanded role of becoming a member of parliament. Women's participation in legislative elections shows that there is 
progress for a democratic process that is participatory in culture and of course this makes women richer in fulfilling their rights (Lumiu, 2014).

In this post-reform era, women's participation in politics is a form of women's emancipation to achieve gender equality. The presence of women in the political sphere as evidenced by women's participation in the legislature is an absolute requirement for the creation of friendly and gender-sensitive public policies. Without adequate participation of women in the legislature, the tendency to place men's interests at the center of policymaking will be difficult to avoid.

Women's participation is a guaranteed human right in the 1945 Constitution article 27 paragraph (1) which reads: "All citizens are at the same position in law and government and must end the law and government with no exception". This means that the Constitution has guaranteed the equal rights and obligations of every citizen including men and women. That mandate was strengthened by Article $28 \mathrm{~d}$ paragraph (3) which reads: "Every citizen has the right to have the same opportunity in government", and Article 28i paragraph 2 which reads: "Everyone is free from discriminatory treatment on any grounds and entitled to protection against discriminatory treatment ".

The Constitution has explained that discrimination is free, meaning that women have full rights to be in the political sphere, as seen from the involvement of women in the legislature. The involvement of women in the legislature is not something new. In the history of the struggle of women, women's participation in development has progressed, especially in the fields of education, economy, and government. In the history of the struggle of Indonesian women, many women leaders have become the reference for changes in development in Indonesia such as RA Kartini, Cut Nyak Dhien, Martha Christina Tiahahu, Dewi Sartika, Nyi Ageng Serang, Cut Nyak Meutia, R Rasuna Said, Fatmawati Soekarno and so on. It means that from the beginning of women's independence, they had been involved in the public sphere, although the socioculture of the community was still strong in considering women only served in the domestic sphere.

There have been many studies on the role of women's political participation in the legislature, including Lumiu (2014) and Purwanti (2015). The similarity of this research with the above research is that they both examine the participation of women in JURNAL PAPATUNG: VOL. 1 No. 1 Tahun 2019 
the political sphere, but the difference between this study and previous research is that this study will examine in depth the causes of decreased political participation in the legislature of West Sumatra Province.

Based on the background above, the purpose of this study is to describe the factors causing the decline of women's involvement in the legislative elections in the Province of West Sumatra.

\section{B. LITERATURE REVIEW}

\section{Understanding Participation}

KBBI explained that participation is a person who participates in an activity, be it a conference, meeting, seminar, exhibition and so on. According to Verhangen in Mardikanto (2013), participation is a form of participation of a person (individual or community member) in a certain activity. The participation or involvement referred to here is not passive but is actively directed by the person concerned. Therefore, participation would be more accurately interpreted as the participation of a person in a social group to take part in community activities, outside of work or his own profession.

Meanwhile, according to Sastropeotro (1998), participation in the mental involvement or thoughts and feelings of a person in a group situation that encourages to contribute to the group in an effort to achieve certain goals and also take responsibility for the business concerned.

So from some of the above understanding, it can be concluded that participation is involvement or participation both thoughtfully, financially and powerfully in responding to activities that carry out and support the achievement of objectives responsible for its involvement.

\section{Forms of Participation}

Participation in community groups has a different way as suggested by several experts, one of which is in the opinion of Effendi (2007), participation takes two forms, as he pointed out below, namely:

a. Vertical participation is a form of certain conditions in the community involved in or taking part in a program of another party, in a relationship where the community is a subordinate position. 
b. Horizontal participation is where the community is not impossible to have an initiative where each member/group of people participates horizontally between one or another, both in conducting joint ventures and in the context of carrying out activities with other parties.

Other opinions expressed by Hamijoyo (2009), there are several forms of real participation, namely:

a. Money participation is participation to facilitate business efforts to achieve the needs of the people who need help.

b. Property participation is participation in the form of donating property, usually in the form of work tools or tools.

c. Labor participation is participation given in the form of personnel for the implementation of businesses that can support the success of a program.

d. Skills participation, which is giving encouragement through the skills they have to other community members who need it.

\section{Political Participation}

According to McClosky in Budiardjo (2007), political participation is the voluntary activities of citizens through which they take part in the process of electing rulers, and directly or indirectly, in the process of public policy formation.

According to Samuel P. Huntington and Joan M. Nelson in Budiardjo (2007), political participation is the activity of citizens acting as individuals, intended to influence government decision making. Participation can be individual or collective, organized or spontaneous, steady or sporadic, peaceful or violent, legal or illegal, effective or ineffective. According to Budiyanto (2007), political participation is the activity of a person or group of people to actively participate in political life, such as electing state leaders or efforts to influence government policy.

According to Surbakti (1992), political participation in countries that implement a democratic political system is a citizen's right but in reality, the percentage of participating citizens differs from one country to another. In other words, not all citizens participate in the political process.

In addition, MGMP (2012 :), explained the function of political participation for the government namely (a) Supporting government programs. This means that JURNAL PAPATUNG: VOL. 1 No. 1 Tahun 2019 
community participation is realized to support political programs and development programs. (b) Voice the interests of the community as input. Community participation as an organization that voices the interests of society for input to the government in directing and promoting development, social organizations and social-political organizations is an example and function of that politics. (c) Perform the control function of the government and its policies. The control function is actually owned by the wider community be it the legislative body, the press, or individuals. Thus, political participation is a mechanism for implementing the control function of the government in implementing participatory political policies and culture. That is a political culture that is democratic and will impact on the formation of a democratic and stable political system.

\section{Legal Basis for Women's Participation in the Legislature}

The existence of regulations regarding the 30 percent quota obligation for women legislative candidates is one of the important achievements in the journey of Indonesia's democracy after the reform. The regulation is contained in a number of laws, namely Law no. 31 of 2002 concerning Political Parties, Law No. 12 of 2003 concerning General Elections, Law No. 2 of 2008 concerning Political Parties and Law No. 10 of 2008 concerning General Elections of Members of the DPRD which also contains rules relating to the 2009 elections.

a. UU no. 2 of 2008 mandated political parties to include women's representation of at least 30 percent in the establishment and management at the central level. This 30 percent figure is based on the results of United Nations research which states that a minimum of 30 percent allows for a change and has an impact on the quality of decisions taken in public institutions.

b. UU no. 10 of 2008 requires political parties to include 30 percent representation of women at the central level management. These requirements must be fulfilled by political parties in order to participate in elections.

c. UU no. 10 of 2008 Article paragraph 2 which regulates the implementation of the zipper system, i.e. every 3 prospective legislative candidates, there is at least one female candidate for the legislative candidate. 
Although the representation of women in the realm of practical politics has been pushed in such a way through various policies, the results are still far from satisfying (Hidayah, 2018).

\section{RESEARCH METHODS}

This study used qualitative research methods. The reason researchers used qualitative research methods was that this study would look at and know the causes of the low participation of women in the West Sumatra DPRD. This qualitative method is used considering several considerations. First, qualitative research methods are useful for a deeper understanding of the meaning (subjective meaning and interpretation) and the context of behavior and processes that occur in factors related to low participation. Second, qualitative research methods are useful for expressing the process of events in detail, so that the dynamics of social reality and the interplay between social realities are known. Third, qualitative research methods are useful for knowing social reality from the actor's perspective. Fourth, qualitative research methods produce richer information than quantitative methods and this is very useful for increasing understanding of social reality (Afrizal, 2014).

\section{RESULT AND DISCUSSION}

Various legal instruments have legitimized women's political participation even though women and the political stage are still two things that are not easily linked. Where Law No. 10 of 2008 has required political parties to include 30 percent representation of women at the central level management. These requirements must be met by political parties in order to participate in the election. Other regulations related to women's representation are contained in Law no. 10 of 2008 Article paragraph 2 governing the implementation of the zipper system, that is, for every 3 prospective legislative candidates, there is a minimum of one woman legislative candidate.

The 2019 general elections have taken place on April 17, 2019. One thing that should be appreciated is the efforts of political parties to maximize the 30 percent quota for female candidates. However, the representation of women in the world of formal politics is still very low compared to men. The political world is always associated with 
the public realm that is relatively close to men, socio-culture can not be separated from its cultural roots where the majority of society is still thick with patriarchal ideology.

The West Sumatra Election Commission (KPU) has set 65 candidates elected as members of the West Sumatra DPRD for the period 2019-2024. Viewed from the friendly and gender-sensitive side, there is a decrease in the number of women participating in the Province of West Sumatra. In 2014-2019 the number of women involved in the legislature amounted to 7 women, while in 2019-2024 it decreased by 4 women, meaning that the number of women represented in the West Sumatra DPRD fell by $40 \%$. In the 2014-2019 period, seven members of the West Sumatra DPRD from women were Sitti Izzati Aziz (Golkar), Marlina Suswati (Golkar), Rahayu Purwanti (PKS), Zusmawati (Hanura), Armiati (Hanura), Riva Melda (PDI P) and Endarmy (Nasdem). Whereas there are four female candidates who get seats in the 2019 Election based on the KPU recapitulation results, namely Sitti Izzati Aziz (Golkar), Yunisra (Gerindra), Leli Arni (PDIP) and Mesra (Gerindra).

Of the 4 women who sit in the legislature, 3 of them are women who have just tried to sit in the legislative seat. Only Siti Izzati Aziz who was a member of the 20142019 DPRD was able to maintain her seat in the West Sumatra DPRD with a total of 7,966 votes. This means that 6 legislative women in the 2014-2019 period were not elected as members of the West Sumatra Province DPRD.

Based on findings in the field, the low participation of West Sumatra women in the political sphere can be explained in several perspectives, namely:

1. A perspective that considers the strength of the patriarchal paradigm in the majority of Indonesian society, where men have more authority to make policies. The patriarchal mindset tends to place women under the authority of men. Women are considered as parties who do not have autonomy and consistency in all fields. It is this practice that is rooted in the mindset of the people who are directing and tend to be hereditary for the next period of political parties so that it is considered as something that is understood and adhered to together. Even patriarchal culture is increasingly justified when interpreted in terms of Islamic religion which is more in favor of male interests. 
2. The mindset of the people who tend to idolize brave men and bears to be chosen. Also public understanding of the division of roles between public space and domestic space. Where the best is women who take care of household affairs.

3. The lack of socialization and activities of women legislative candidates with the community. Women candidates seem to appear at the time of the election so that it is not known to the public. Even though the public does not fully understand the essence of democracy and the importance of elections as a means to build a gender-equitable future of Indonesia.

4. Women don't choose women. This means that the low awareness of women in choosing female legislative candidates, due to distrust with the ability of women to increase the electability of political parties. This relates to women's financial, financial and social capital.

5. Political organizations do not really have a full commitment to empowering women. Submission of female candidates for legislative candidates by political parties is only done to meet the $30 \%$ election requirements without providing debriefing and taking into account their potential.

Based on the perspective above, it can be concluded that the marginal cycle is occurring in the DPRD of West Sumatra Province, where women tend not to have political independence. The presence of women in political parties is positioned as an object, not a subject. So that women's political participation tends to below.

In addition, based on observations in the field which is a barrier to the decline in women's political participation is the multi-role of women, namely as housewives, workers and professional societies. According to researchers, women have limited time to enter politics because of the multi-role role. However, the strategic efforts made by political organizations to overcome barriers and accommodate the multi-role of women are also non-existent. So the socio-cultural situation is rooted and difficult to change. Example: The number of activities of DPRD members who work outside the city and activities outside working hours, the husband's fear is when the wife overrides her responsibilities as a housewife and takes care of children. Therefore, women's political participation becomes invisible when social and family support is difficult to accept the main tasks of women in parliament. 
So comprehensively, the role of women is very limited in policy making and decision making and leadership positions that are still held by men due to socio-cultural conditions which make it difficult for women to be fully involved in it. In addition, the level of education of women whose majority is still low further exacerbates the problem and does not convince the public to have female candidates. So many women do not care about political rights, especially towards female candidates.

\section{E. CONCLUSION}

The West Sumatra Election Commission (KPU) has set 65 candidates elected as members of the West Sumatra DPRD for the period 2019-2024. However, in the Province of West Sumatra, there was a decrease in the number of women participating, in 2014-2019 the number of women involved in the legislature amounted to 7 women, while in 2019-2024 it decreased by 4 women, this figure decreased by $40 \%$ from before. Of the 4 women sitting in the legislature, 3 of them were women who had just tried to sit in the legislature. Only 1 woman who was a member of the 2014-2019 DPRD was able to maintain her seat in the West Sumatra DPRD with a total of 7,966 votes.

Factors causing a decline in the number of women's representation in the political sphere. This is due to (1) a perspective which considers the strength of the patriarchal paradigm in the majority of Indonesian society, (2) women have a multi-dual role to take care of domestic and public life, (3) public mindset that tends to idolize brave men and bears to be elected, (4) Women do not choose women, meaning the low awareness of women to choose women legislative candidates, (5) Political organizations do not really have full commitment to empower women. Comprehensively, the role of women is very limited in policy making and decision making and leadership positions that are still held by men due to socio-cultural conditions which make it difficult for women to be fully involved in it.

\section{REFERENCES}

Afrizal. (2014). Metode Penelitian Kualitatif. Jakarta: Rajagrafindo Persada. Budiarjo, M. (2007). Dasar-Dasar Ilmu Politik. Jakarta: PT. Gramedia Pustaka Utama. 
Effendi, N. (2007). Perencanaan Pembangunan Partisipasi dalam Perspektif Teori Antropologi Pembangunan. Dalam Antropologi dan Pembangunan di Masyarakat Lokal, Padang: Antropologi Unand.

Hamijoyo, L. (2007). Pengapuran Sendi atau Osteoartritis. Perhimpunan Reumatologi Indonesia. http://reumatologi.or.id/reuarttail?id=23 (Diakses pada tanggal 24 Mei 2019).

Lumiu, V. (2015). Partisipasi Politik Perempuan dalam Pemilu Legislatif Tahun 2014 di Kecamatan Siau Barat Selatan1. Jurnal Politico, 2(6).

Mardikanto, T., \& Soebianto, P. (2013). Pemberdayaan Masyarakat dalam Perspektif Kebijakan Publik. Bandung: Alfabeta.

Purwanti, A. (2015). Partisipasi Perempuan Pada Lembaga Legislatif Tahun 2014-2019 Di Provinsi Jawa Timur. Masalah-Masalah Hukum, 44(2), 190-199.

Rahman, M. (2009). Studi Kompetensi Profesional Guru Pendidikan Agama Islam SMP di Kabupaten Cirebon (Studi Pengurus MGMP PAI SMP Kabupaten Cirebon). Skripsi. Semarang: IAIN Walisongo Semarang.

Sastropoetro, S. R. A. (1988). Partisipasi, Komunilasi, Persuasi, dan Disiplin dalam Pembangunan Nasional. Bandung: Alumni.

Surbakti, R. (1992). Memahami Ilmu Politik. Jakarta: Gramedia Widya Sarana.

Undang-Undang Nomor 2 Tahun 2008 tentang Partai Politik.

Undang-Undang Nomor 10 Tahun 2008 tentang Pemilihan Umum Anggota Dewan Perwakilan Rakyat, Dewan Perwakilan Daerah, dan Dewan Perwakilan Rakyat Daerah. 